definitely cotyledonous, these were deformed and incomplete. In the case where the cotyledon replaced the fourth leaf, it consisted of a petiole about 3 in. long, bearing a relatively small lamina split down the centre with the two halves divergent.

(3) The third cotyledon is occasionally borne opposite the first true leaf at one node instead of being at a separate node.

Seedlings showing supplementation grow well into good plants. In general, however, fission and supplementation do lead to local malformation, though twinning does not.

Tricotyledonous brassica plants sometimes bear a pair of true leaves at the first node, or the first or second leaf may be incompletely twinned. Similarly in the wallflower, carnation and Dianthus sinensis, tricotyledony is often accompanied by the occurrence of three true leaves at the first, and sometimes also at the second, node.

Thus pleiocotyledony in brassicas occurs, as I find it, in several forms, counts of which should be made in the progeny of each type of tricotyledonous parent for the various forms can all be found among the offspring of one plant. I have estimated that the $S_{2}$ generation contained 25 per cent pleiocotyls of one kind or another, and a similar percentage has been found in a small test with the tomato. Pleiocotyly in an $S_{2}$ of wallflower, however, is as high as 40 per cent. Full analysis, however, involves growing all the seedlings to a size hitherto impossible in the conditions under which I have worked. I hope to obtain improved facilities in the future and so to obtain adequate counts in the selection lines.

I am indebted to Dr. K. Mather, of the John Innes Horticultural Institution, for advice on the interpretation of these observations.

\section{SCIENTIFIC CENTENARIES IN 1944}

By ENG.-CAPt. EDGAR C. SMITH, O.B.E., R.N.

$A$ MONG the many men of science whose centen$A$ aries occur this year are representatives of England, Scotland, Ireland, France, Belgium, Sweden, Italy, Austria and America. Four hundned years ago, according to Silvanus Thompson, Gilbert was born; three hundred years ago, Castelli, Gascoygne and van Helmont died and Römer was born; two hundred years ago Celsius and Desaguliers died and Lamarck and Mechain were born, while among those who died a century ago were Dalton, Baily, Hope, Henderson and Geoffroy Saint-Hilaire.

On December 10, 1903, the exact tercentenary of the death of William Gilbert was commemorated by a meeting of the Institution of Electrical Engineers held at the Institution of Civil Engineers, at which the Royal Society, the Royal College of Physicians, St. John's College, Cambridge, the cities of Colchester and Westminster and the Société Internationale des Electriciens were represented. The address was given by Silvanus Thompson, who said "that electricians owed an enormous debt of gratitude to Gilbert, who, for them, was pre-eminent among all the great men of Elizabeth's time". The occasion was marked by the presentation to the City of Colchester of a picture representing Gilbert showing his experiments to Queen Elizabeth and her Court. The tomb of Gilbert in Holy Trinity Church, Colchester, gives the year of his birth as 1540, but Silvanus Thompson considered the correct date to be May 24, 1544.
Van Helmont (1577-1644), like Gilbert, was a physician, and for a short time filled a chair at Louvain; but his life was spent in philosophical studies and he was the first to recognize the existence of various aeriform substances to which he gave the name 'gases'. He was born in Brussels but died in Holland. Benedict Castelli (1577-1644) was an exact contemporary of van Helmont, and had the privilege of being taught by, and assisting, Galileo; he held chairs both at Pisa and Rome. William Gascoygne (1612 ?-1644), the inventor of the micrometer and a correspondent of Horrocks and Crabtree, died at about the age of thirty, fighting on the Royalist side at Marston Moor on July 2, 1644. Olaf Römer, the Danish astronomer, was born at Aarhuus, in Jutland, on September 25, 1644, and died at Copenhagen on September 19, 1710. His discovery of the velocity of light was made in Paris, when he was thirty-one; his famous transit instrument was made at Copenhagen, where he held the chair of astronomy. Many of his manuscripts were destroyed in the Copenhagen fire of 1728. The year 1744 saw the death of both Andreas Celsius and John Theophilus Desaguliers. Celsius was born at Uppsala on November 27, 1701. His travels took him to Germany, Italy and France, and then he went to Lapland with Maupertuis to measure an arc of the meridian. According to Cajori, Celsius marked his centigrade thermometer with boiling point as $0^{\circ}$ and freezing point as $100^{\circ}$, and it was his colleague Märten Stromer who inverted the scale. Desaguliers was nearly twenty years senior to Celsius, having been born at Rochelle on March 12, 1683. He was brought to England by his father, a Calvinist pastor who left France on the Revocation of the Edict of Nantes. The child, it is said, was smuggled aboard the refugee ship in a barrel. France's loss was England's gain, for Desaguliers succeeded Keill as a lecturer on experimental philosophy at Oxford, and then in 1713 began his work in London "where," he wrote, "I have with great pleasure seen the Newtonian Philosophy so generally received among persons of all Ranks and professions, and even the Ladies by the help of experiments". At his death, Desaguliers was buried in the Savoy. Of the two Frenchmen, Lamarck and Mechain, the former was born in the village of Bazentin (Somme) and the latter at Laon (Aisne). Lamarck began life as a soldier, and then held a post in a Paris bank. In 1774 he became a keeper in the Jardin des Plantes, and there, for a quarter of a century, he lectured on invertebrate zoology. He died in 1829, blind and poor. Pierre F. A. Mechain was a geodesist as well as an astronomer and hydrographer, and it was while still employed on the extension of an arc of the meridian to Barcelona that he died on September 20, 1805 .

Coming to those who died a hundred years ago, one of the most famous was Etienne Geoffroy SaintHilaire, who was born at Etampes on April 15, 1772, and who did great work both for the Jardin des Plantes and the Museum. In Scotland, fow were better known than Thomas Henderson (1798-1844) and Thomas Charles Hope (1766-1844). Henderson, a native of Dundee, began life as a lawyer's clerk, but his studies led him to become acquainted with Wallace and Leslie, and through his papers he gained recognition as an astronomer. After a year or two at the Cape of Good Hope, on October 1, 1834, he became the first Astronomer Royal for Scotland. His contemporary, Hope, was always a chemist, and from 1799 until 1843 occupied the chair of chemistry in 
the University of Edinburgh, previously held by Black. To him we owe the discovery of the maximum density of water. The centenary of John Dalton falls on July 27 of this year, but any commemoration must inevitably be clouded over by the results of the air raid of December 24, 1940, when the premises of the Manchester Literary and Philosophical Society were completely destroyed. From 1817 until 1844 Dalton was president of the Society, and within its walls he taught, lectured and experimented. The Society had an unequalled collection of his apparatus, but after digging among the ruins the only things found were his gold watch, a spark eudiometer and some charred remains of letters and note-books. A month after Dalton passed away in Manchester, Francis Baily died in London, after a life devoted to astronomy and kindred subjects. "Few men have left behind them so enviable a reputation. $\mathrm{He}$ was gentle as well as just; he loved and sought truth; he inspired in an equal degree respect and affection."

As is usual in these annual reviews of the centenaries of men of science, names of notable men born a century ago crowd closely upon one another, but it will perhaps be agreed that all those mentioned below have claims to recognition. Among the ranks of the physicists born in 1844 were Sir William F. Barrett (died 1925), who for more than thirty years held a chair in the Royal College of Science, Dublin; Sir William Abney (died 1921), who did much to put photography upon a scientific basis; and Ludwig Boltzmann (died 1906), professor of mathematical physics in the University of Vienna. Boltzmann died a tragic death, and his successor, F. Hasenöhrl, was killed in action on the Italian front in 1915. The chemists born in 1844 include Prof. J. Emerson Reynolds (died 1920), who occupied for twenty-eight years the chair of chemistry in the University of Dublin, and Ferdinand Hurter (died 1898), a native of Schaffhausen, Switzerland, who came to England in 1867 and became principal chemist to the United Alkali Company. Among astronomers, Prof. W. R. Brooks (died 1921) of the United States was famous as a 'comet hunter'. Charles Trépied (died 1907) was for many years director of the Observatory at Bouzariah, eleven kilometres from Algiers, while Annibale Ricco (died 1919), though he began life as an engineer, for nineteen years directed the observatory of Catania and Etna, his special subject being solar physics. In another sphere of scientific activity, Henry Alleyue Nicholson (died 1899) held professorships at St. Andrews and Aberdeen, and was Lyell medallist in 1888, while Auguste Michel-Lévy (died 1911) was director of the Geological Survey of France. A notice of the life and work of Michel-Lévy was read at a sitting of the Paris Academy of Sciences on December 21, 1914, under the shadow of war. The opening sentences ran, "Aux heures les plus graves de notre histoire nationale, l'Académie des Sciences a toujours tenu a proclamer bien haut sa foi inébranlable dans les destinees de la Patrie en n'interrompant en rien l'ordre régulier de ses travaux. C'est pourquoi, alors que notre territoire est encore envahi par l'ennemi, l'un de vos Secrétaires perpétuels vient, comme de coutume, vous rappeler en cette séance annuelle le souvenir de l'un de nos confrères disparus."

\section{O BITUARIES}

Sir Edward Poulton, F.R.S.

Edward Bagnall Poulton, who died on November 20, was born on January 27, 1856. His school life was spent at Oakley House, Reading, until he was nearly seventeen, when he commenced work in the office of his father, who was an architect. His interest, however, was so obviously in science that he was allowed to work for a scholarship, attending Rolleston's lectures at Oxford. He obtained an open scholarship in science at Jesus College in 1873, and after a crowded three years took a first class in the honour school of natural science. Next year he was appointed demonstrator in zoology under Rolleston, whose virile personality greatly impressed him. But working as one of his staff under him was a very different thing from being one of his students, and Poulton could do little research. During the long vacation, however, he was inspired by Foster and Balfour's work on embryology to follow their methods, and as a result was given a class to teach in that subject. His income being inadequate, he studied for a University scholarship in geology under Prestwich, eventually obtaining the Burdett-Coutts Scholarship. Thus it came about that, having resigned his demonstratorship, his first research was conducted on a geological subject, and his first paper was published in 1880 on remains in quaternary sands at Reading.

Rolleston was succeeded by Moseley in 1881 and Poulton, by now lecturer at Keble and Jesus Colleges, found him as helpful as Rolleston had been difficult. Moseley suggested that he should investigate some Challenger material, and as a result of his studies three papers were published in 1883 on the tongues of several Australian animals, including Ornithorhynchus. An investigation of the structure of the hair of this primitive creature then followed, sections of the head of an immature specimen having been lent by Dr. W. K. Parker. This resulted in a discovery of fundamental importance, for Poulton announced in 1888 that Ornithorhynchus possesses true teeth which cut through the gums but are replaced by horny plates.

But although he was professionally occupied with morphology, Poulton's real interest was in living insects. Such entomological studies as he saw being conducted by Westwood at Oxford did not, however, appeal to him, for they were concerned mainly with systematics. Poulton had read Wallace's essays on natural selection in $\mathrm{I} 878$, and these aroused what he described as "a lifelong delight" in the subject of the coloration of animals, particularly of insects. Weismann's studies in the theory of descent, of which he read in 1883 a translation by his friend $R$. Meldola, contained an account of variation in the colour of a caterpillar according to its surroundings, which especially interested Poulton, as it recalled observations he had made in boyhood upon that very species.

$\mathrm{He}$ began to work at once on that subject, and, amidst his morphological work, produced during 1884-88 a succession of papers on the colours of larvæ and pupæ and on experiments to test the factors influencing them, and their survival value. These researches led to his election to the Royal Society in 1889 , and in 1890 his great work "The Colours of Animals" at once set him in the front 